Mihaylova, L., \& Papazov, E. (2018). Using accounting information for strategic decision-making in a multi-segmented company. Copernican Journal of Finance \& Accounting, 7(1), 21-33. http:// dx.doi.org/10.12775/CJFA.2018.002

\author{
Lyudmila Mihaylova* \\ University of Ruse "Angel Kanchev" \\ Emil Papazov** \\ University of National and World Economy
}

\title{
USING ACCOUNTING INFORMATION FOR STRATEGIC DECISION-MAKING IN A MULTI-SEGMENTED COMPANY
}

Keywords: a multi-segmented company, strategic decisions, accounting information, operating segments.

J E L Classification: M21.

Abstract: The reason of being of corporate accounting is not only to record, interpret
and present data about existing business processes, but also to provide information for
supporting main decision-making activities of management. This article presents basic
problems outlining the relationship between accounting and strategic management of
companies. The main ideas are connected with the philosophy of presenting informa-
tion in financial and management reports, on the one hand, and the levels of manage-
ment activities and their relationship to the development strategy of the organization,
on the other hand. The aim is to trace the relationship between the segmental accoun-
ting and the strategic management of diversified organizations and to highlight pro-
blem areas, deserving management attention. The research methods of analysis and

Date of submission: May 15, 2018; date of acceptance: June 3, 2018.

* Contact information: lmihaylova777@gmail.com, "Angel Kanchev" University of Ruse, Faculty of Business and Management, Studentska Str. 8, Ruse-7017, Bulgaria, phone: + 359879005 325; ORCID ID: https://orcid.org/0000-0001-8566-1761.

** Contactinformation:epapazov@gmail.com,University of Nationaland World Economy, Business Faculty, Studentski Grad, Sofia-1700, Bulgaria, phone: + 359879005 316; ORCID ID: https://orcid.org/0000-0002-7940-0474. 
synthesis have been used. The outcomes of the research show that choosing a proper cost structure and allocation basis at operating segment level will contribute to increasing the capabilities of managers to make better corporate strategic decisions.

\section{IIIINTRODUCTION}

In a market environment, the progress of a business is dependent on continuous improvement of its long-term competitiveness based on attracting of suitable investors, ensuring of proper market positions, setting-up of optimal business portfolios and creating of conditions for rational use of resources. In this respect, the tasks of company's accountancy consist not only of registration, interpretation and presentation of already undergoing business processes and phenomena, but also of information provision of the activities connected with taking managerial decisions of different nature - strategic, tactical and operational.

Strategic decisions are inherent to the senior management of a company and are related mainly to the development of new products, exploration of new markets or utilization of new technologies and resources. Following its strategy, every business organization tries to find a position in the sector, in which it is active, and defend this position as long as possible (Papazov \& Mihaylova, 2015; Ciemleja \& Lace, 2011; Mitev, 2016; Arun, 2015).

Principally, each of the main components of a company's strategy is a subject of attention by different stakeholders, and therefore, when making strategic decisions, there is a need to look for informational links between them. They also appear in the tracking of the information flow, as well as in the ways of its summarizing and presentation to the upper management.

The accumulated experience shows that financial statements, having often a mandatory character, present, as a rule, mostly material and financial results of company's development. The obtained information enables analysts to assess the enterprise's long-term sustainability, liquidity and profitability. However, it is more difficult to evaluate all other strategic parameters in order to take appropriate management action, if required.

The difficulty is compounded by the fact that companies - in order to keep or raise revenues and profits - are increasingly using diversification (multisegmentation) techniques as a strategic tool, i. e. entering other related or unrelated businesses, regardless of the size and nature of company's activities so far. Diversification is becoming a preferable strategy, especially in times of eco- 
nomic crises. (For further details, see Papazov \& Mihaylova, 2011; Trifonova \& Atanassov, 2016).

The diversification of a company's business requires undertaking of specific strategic actions, substantiated by sufficient volume and content of information. The ways this information is reported and presented to senior management depend usually on the planned objectives, the imposed internal organizational and management structure, and the offered variety of products and services. In this respect, the emphasis on management information is placed in relation to the products or services and is concentrated in the so-called "strategic business units". In more recent times and mainly in the accounting literature, the term "strategic business unit" is substituted by the term "operating segment" developed for financial reporting purposes and endorsed by the International Financial Reporting Standard 8 - Operating Segments (European Commission, 2007; IFRS 8, 2017).

The IFRS 8 defines the operating segment as "a component of an entity that engages in business activities from which it may earn revenues and incur expenses (including revenues and expenses relating to transactions with other components of the same entity); whose operating results are regularly reviewed by the entity's chief operating decision maker to make decisions about resources to be allocated to the segment and assess its performance; and for which discrete financial information is available". The purpose of the regulatory norm is to assure first and foremost publicity of information broken down by segments, when it comes to a company that has a complex (diversified) character and is traded (or is about to be listed) on the stock exchange (Ernst \& Young, 2009).

In this article, the focus will be placed on the relationship between the strategic decision-making and accounting reporting for managerial purposes at strategic business unit (or operating segment) level. This relationship is important because the taken strategic decisions will be based on reliable and timely reporting information, which will make them appear to the company's stakeholders as reasonably justified.

For the purposes of this investigation, the terms "strategic business unit" and "operating segment" will be used as equivalent and interchangeable, although they have in fact a complementary nature showing common characteristics, but also peculiarities that distinguish them from one another. 


\section{METHODOLOGY OF RESEARCH}

The results of the investigation will be presented after applying the analyticalsynthetic method by offering a cascading hypothetical case study. The compiled example will illustrate that reporting by strategic business units (operating segments) is a prerequisite not only for a proper analysis of corporate performance, but also for tracing of future strategic directions initiated by senior managers.

\section{RESEARCH CONTEXT: ACCOUNTING INFORMATION AND STRATEGIC DECISION-MAKING}

Practitioner's views on the relationship between strategic management and financial accounting have endured changes over time, but no consensus on this issue has been reached so far. There are many interpretations arising from the different management perspectives. However, the view about the need for mutual penetration between accounting information and strategic decision-making with a focus on costs and benefits of company's activities seems to prevail (Hart \& Roslender, 2003; Simeonov \& Lambovska, 2012).

Analyzing sales revenues of individual products or product lines can be done on the basis of financial reporting, as well as on the basis of intercompany estimates made for management purposes. The strategic analysis could be organized also by business segments, created on cost-revenue base and consistent with the followed firm strategy. The revenue could be directly related to an operating segment or be part of the enterprise's revenue that could be addressed to a relevant strategic business unit, if an appropriate allocation base is available, independent of fact where it comes from - external or internal customer sales.

Specific in this case is that from the point of view of financial reporting, the costs of the operating segment do not include general and administrative expenses, including costs of the central management and other costs arising at enterprise level and relating to its management as a whole (figure 1). In the management accounting, however, there are no such constraints, because cost allocation complies principally with the policy of managers at different levels. 
Figure 1. Segmented Structure of a Company
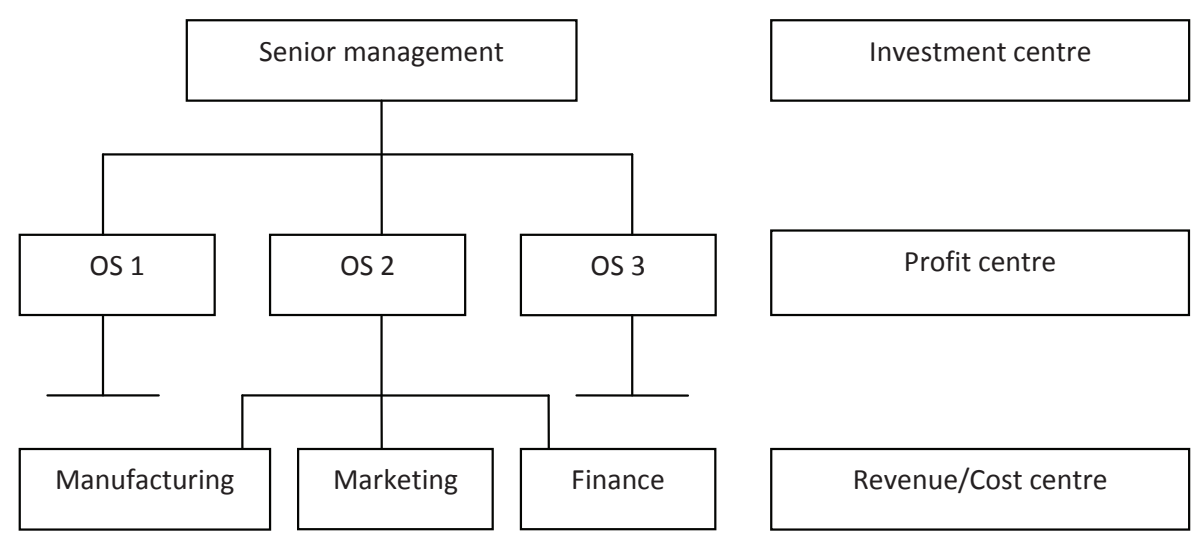

S o u r c e : adapted from: Papazov, 2012, p. 110.

The financial reporting in diversified enterprises is tied to the accounting policies adopted by their management. In this regard, it is important to define the scope of the assets of the operating segments, i.e. those assets which have been engaged in the operational activities of the segment or can be attributed to it on a reasonable basis. In some cases, for strategic management purposes, revenues, expenses, or assets may be allocated to certain operating segments on a basis that is reasonably chosen by the entity's management, but from the point of view of external users the financial statements could be considered subjective, controversial, or difficult to understand (the examples of complex engineering manufacturing, chemical or similar production). There are also opposite cases, when the entity's management decides that for the purposes of management reporting it will not refer to revenues, expenses or assets for any of the segregated operating segments, although there is a reason for such an action due to existing financial reporting norms.

To justify whether an income or expense is attributable to a relevant operating segment, managers need to assess whether associated risks and returns are product-dependent variables. For example, when advertising a product of a company, it is sometimes difficult to assess whether risks and benefits relate to that product only or would have an impact on the entity as a whole. Accordingly, the question of revenue and expense allocation arises. 
The practical experience shows that the management reporting system usually provides good evidence of the prevailing sources of risks and expected returns that are also used for financial reporting purposes by operating segments. In $90 \%$ of the cases, a unit renders in its statements an account of information by operating segments in the same way, as it reports strategically important facts and circumstances to the senior management. The idea of such solutions is to increase the intelligibility of the received information and to respond to the expressed needs of investors, creditors and others for risk and return information related to company's products (Bojarenko, 2017; Hofbauer, 2017, pp. 20-31; Šimberová, 2008).

Companies are also trying to utilize methods providing full transparency of the processes inside it. They also implement techniques giving opportunities for the company's management to accomplish different goals simultaneously. (Škoda, Lengyelfalusy \& Gabrhelová, 2017; Khocha, 2017; Ruland, 1984; Pepur, Mihanović \& Pepur, 2013).

For the purpose of financial reporting, an operating segment should be identified, if the predominant part of its revenue arises from sales to external customers. In this respect, IFRS 8 sets three important conditions: First, sales revenue as a whole (i.e. to both external and internal customers) are $10 \%$ or more of the total revenue of all sectors. Second, the financial result (differentiated in profit or loss) of an emerging segment is $10 \%$ or more of the total financial result (differentiated in profit or loss) for the company as a whole. Third, the segmental assets are $10 \%$ or more of the company's total assets.

At the discretion of company's management, an operating segment eligible for reporting in the prior period, may continue to be reported in the current period, even though it does not meet the accounting standards, but continues to be of strategic importance for the company's management. The decision is taken in line with the followed strategy and is a priority of the senior management. There is also an opposite variant: If the operating segment is identified as being subject to reporting in the current period because it meets required conditions, then the information for prior periods should be revised for comparative purposes, unless it is impracticable to do so. When such actions occur, strong relationships between financial and managerial accounting, on the one side, and strategic management, on the other, emerge. 


\section{STRATEGIZING IN A MULTI-SEGMENTED COMPANY BASED ON ACCOUNTING INFORMATION}

Reporting by operating segments (strategic business units) and achieving comparability of results is a prerequisite for analyzing business performance indicators. On this basis, strategic management decisions can be made, for example in connection with a possible restructuring of the company's product portfolio.

When analyzing financial result of an operating segment (strategic business units), there are some issues that are essential from strategic point of view. If calculating the financial result of an operating segment (strategic business units), both variable and fixed costs (direct and indirect; distributed on a "reasonable" basis) should be taken into account. However, the formation of some of the fixed indirect costs (for example, rental costs of a production facility; costs pertaining to machinery and equipment used for manufacturing in all segments of the enterprise) appears perhaps a result of past decisions of the senior management and a consequence of earlier adopted accounting policy. It follows that the financial result generated by the operating segment (strategic business unit) will strongly be influenced by the already adopted methodology underlying cost allocation calculation. When defining it, account should be taken of the specific features of each activity, so that it can be applied systematically in the enterprise.

As stated above, for the purpose of financial reporting, the operating segment costs do not include those made for overall purposes, as well as those used for the needs of company's senior management. If we take in this respect the example of a leather manufacturer, things would look like this (table 1).

Table 1. Financial results by operating segments (OS) of a company (1)

\begin{tabular}{|l|c|c|c|c|c|}
\hline \hline \multicolumn{1}{|c|}{ Indicators } & $\begin{array}{c}\text { OS “Men's } \\
\text { shoes” }\end{array}$ & $\begin{array}{c}\text { OS “Lady's } \\
\text { shoes” }\end{array}$ & $\begin{array}{c}\text { OS “Children's } \\
\text { shoes” }\end{array}$ & $\begin{array}{c}\text { OS “Leather } \\
\text { accessories” }\end{array}$ & Total \\
\hline \hline Sales revenues & 600 & 400 & 400 & 300 & 1700 \\
\hline Variable costs & 400 & 310 & 350 & 200 & 1260 \\
\hline $\begin{array}{l}\text { Fixed technological costs } \\
\text { after distribution on the } \\
\text { basis of variable costs }\end{array}$ & 95 & 74 & 83 & 48 & 300 \\
\hline Financial result & 105 & 16 & -33 & 52 & 140 \\
\hline \hline
\end{tabular}

S o u r c e : authors' own analysis. 
The analytical calculations are made from the point of view of financial reporting. The preparation of the information is primarily intended for third parties. The data show that the enterprise as a whole has a profit of 140 units. If the reported 300 unit costs are allocated on a variable cost basis, the operating segment "Children's shoes" indicates a loss of 33 units.

If we choose under the same circumstances another basis for the distribution of fixed costs, for instance the sales revenues, the results will be as follows (table 2).

Table 2. Financial results by operating segments (OS) of a company (2)

\begin{tabular}{|l|c|c|c|c|c|}
\hline \hline \multicolumn{1}{|c|}{ Indicators } & $\begin{array}{c}\text { OS “Men's } \\
\text { shoes” }\end{array}$ & $\begin{array}{c}\text { OS “Lady's } \\
\text { shoes” }\end{array}$ & $\begin{array}{c}\text { OS “Children's } \\
\text { shoes” }\end{array}$ & $\begin{array}{c}\text { OS “Leather } \\
\text { accessories” }\end{array}$ & Total \\
\hline \hline Sales revenues & 600 & 400 & 400 & 300 & 1700 \\
\hline Variable costs & 400 & 310 & 350 & 200 & 1260 \\
\hline $\begin{array}{l}\text { Fixed technological costs } \\
\text { after distribution on the } \\
\text { basis of sales revenues }\end{array}$ & 105 & 70 & 70 & 55 & 300 \\
\hline Financial result & 95 & 20 & -20 & 45 & 140 \\
\hline \hline
\end{tabular}

S o u r c e : authors' own analysis.

In the second case the result is identical. It turns out that the operating segment "Children's shoes" is again losing, although the loss is less.

If the question arises as to whether or not the total expenses of corporate governance should be allocated or not in pricing and determining the profits of individual strategic business units, then more problems arise. The above example can be complemented for management reporting and strategic analysis purposes. We choose the option with distribution of fixed costs on revenue basis. Assuming that the general business costs are allocated on the same basis, the results will look like the following (table 3).

Table 3. Financial results by operating segments (OS) of a company (3)

\begin{tabular}{|l|c|c|c|c|c|}
\hline \hline \multicolumn{1}{|c|}{ Indicators } & $\begin{array}{c}\text { OS “Men's } \\
\text { shoes” }\end{array}$ & $\begin{array}{c}\text { OS “Lady's } \\
\text { shoes” }\end{array}$ & $\begin{array}{c}\text { OS “Children's } \\
\text { shoes” }\end{array}$ & $\begin{array}{c}\text { OS “Leather } \\
\text { accessories” }\end{array}$ & Total \\
\hline \hline Sales revenues & 600 & 400 & 400 & 300 & 1700 \\
\hline Variable costs & 400 & 310 & 350 & 200 & 1260 \\
\hline
\end{tabular}


Table 3. Financial results by operating segments (OS) of a company (3)

\begin{tabular}{|l|c|c|c|c|c|}
\hline \hline \multicolumn{1}{|c|}{ Indicators } & $\begin{array}{c}\text { OS “Men's } \\
\text { shoes” }\end{array}$ & $\begin{array}{c}\text { OS “Lady's } \\
\text { shoes” }\end{array}$ & $\begin{array}{c}\text { OS “Children's } \\
\text { shoes” }\end{array}$ & $\begin{array}{c}\text { OS “Leather } \\
\text { accessories" }\end{array}$ & Total \\
\hline \hline Contribution & 200 & 90 & 50 & 100 & 440 \\
\hline $\begin{array}{l}\text { Fixed technological costs } \\
\text { ffter distribution on the } \\
\text { basis of variable costs }\end{array}$ & 105 & 70 & 70 & 55 & 300 \\
\hline Financial result I & 95 & 20 & $-\mathbf{2 0}$ & 45 & 100 \\
\hline $\begin{array}{l}\text { SG\&A expenses* after } \\
\text { distribution on the basis of } \\
\text { variable costs }\end{array}$ & 35 & 23 & 23 & 19 & 100 \\
\hline Financial result II & 60 & -3 & -43 & 26 & 40 \\
\hline \hline
\end{tabular}

${ }^{*}$ SG\&A stands for selling, general and administrative (expenses).

S o u r c e : authors' own analysis.

After the additional non-accounting calculations, a second strategic business unit is now at loss. In such situations, the firm's management usually decides on a strategic plan to gradually phase out the business units and restructure its product portfolio. If such a solution is used, the indicators will look like this (see table 4).

Table 4. Financial results by operating segments (OS) of a company (4)

\begin{tabular}{|l|c|c|c|}
\hline \multicolumn{1}{|c|}{ Indicators } & OS “Men's shoes” & $\begin{array}{c}\text { OS “Leather } \\
\text { accessories” }\end{array}$ & Total \\
\hline \hline Sales revenues & 600 & 300 & 600 \\
\hline Variable costs & 400 & 200 & 300 \\
\hline Contribution & 200 & 100 & 300 \\
\hline $\begin{array}{l}\text { Fixed technological costs after distri- } \\
\text { bution on the basis of variable costs }\end{array}$ & 200 & 100 & 0 \\
\hline Financial result I & 0 & 33 & 100 \\
\hline $\begin{array}{l}\text { SG\&A expenses } \text { after distribution on } \\
\text { the basis of variable costs }\end{array}$ & 67 & -33 & -100 \\
\hline Financial result II & -67 & 33 & 0 \\
\hline \hline
\end{tabular}

*SG\&A stands for selling, general and administrative (expenses).

S o u r c e : authors' own analysis. 
The enterprise accounts for a loss of 100 units, and following the abovementioned logic, the management should decide to fully restructure the product portfolio of the enterprise or cease its business. This decision seems practically absurd (variant 3 in table 3 shows a positive financial result of 40 units for the company as a whole!), but is indicative for the overall cost analysis by operating segments, which should take into account that:

- The total company's costs affect the overall financial result but are not dependent on the segmental level management. The negative financial result of a strategic business unit obtained after the distribution of total firm expenses (for management reporting purposes), is not fair to be considered an important indicator justifying the cessation or restructuring of the diversified enterprise portfolio (Yonkova, 2005).

- When complying with the financial reporting requirements, specific indicators are not taken into account for the value of the overall business activities and its relationship to the entity's functional (or strategic business) units. These costs, however, inevitably accompany the business and are related to the strategic management and authority of the top managers. This raises the need to integrate financial and management accounting information for the needs of strategic governance in diversified businesses.

- When doing accounting for the needs of strategic management of diversified enterprises, the bases of distribution of the total company costs are often arbitrarily chosen and do not take into consideration the factors that cause them. They should stem from the peculiarities of the operating segment's activities characterized by different opportunities for economic contribution across the enterprise as a whole.

From a strategic point of view, the appropriate benchmark for assessing managerial actions concerning an operating segment (strategic business unit) is the indicator contribution. In addition, an analysis could be undertaken focusing on the costs influenced by managerial decisions and concerning the product portfolio, the organization of the manufacturing process and realization of the sales of the strategic business unit.

The contribution indicator represents the difference between revenue and variable costs calculated by operating segments or for the company as a whole. The specific values for the example under consideration are shown in table 5. 
Table 5. Financial results by operating segments (OS) of a company (5)

\begin{tabular}{|l|c|c|c|c|c|}
\hline \hline \multicolumn{1}{|c|}{ Indicators } & $\begin{array}{c}\text { OS “Men's } \\
\text { shoes" }\end{array}$ & $\begin{array}{c}\text { OS “Lady's } \\
\text { shoes” }\end{array}$ & $\begin{array}{c}\text { OS “Children's } \\
\text { shoes” }\end{array}$ & $\begin{array}{c}\text { OS “Leather } \\
\text { accessories” }\end{array}$ & Total \\
\hline \hline Sales revenues & 600 & 400 & 400 & 300 & 1700 \\
\hline Variable costs & 400 & 310 & 350 & 200 & 1260 \\
\hline Contribution & 200 & 90 & 50 & 100 & 440 \\
\hline Fixed costs & 140 & 93 & 93 & 74 & 400 \\
\hline Financial result & 60 & -3 & -43 & 26 & 40 \\
\hline \hline
\end{tabular}

S o u r c e : authors' own analysis.

If a multi-segmented company uses the contribution indicator for strategic decision-making, the segments reporting negative financial results could be left untouched at least as long as they cover some of the total fixed costs associated with company's business. This, of course, will continue until the company as a whole is profitable.

\section{ConCLUSIONS}

The presented approaches for information provision and justification of strategic decisions in multi-segmented companies depend heavily on the way accounting activities are organized. Choosing properly a cost allocation basis at the operating segment level will lead to increased capabilities of managers to plan, analyze and control the business development. The resulting reporting information may disclose risks and opportunities of individual business units belonging to a complex enterprise and present a true "picture" to the potential investors to facilitate their informed investment decisions. On the basis of the systematic information and under the collaboration with interested third parties, the ability of managers to plan and control business activities will increase while in the same time the chances of a company to develop effectively and competitively will enlarge. 


\section{REFERENCES}

Arun, K. (2015). Effect of knowledge sharing and supply chain management on organizational performance. International Journal of Knowledge-Based Organizations (IJK$B O), 5(3), 19-32$.

Bojarenko, J. (2017). Variability of accounting policies - advantages and disadvantages. Copernican Journal of Finance \& Accounting, 6(3), 9-19. http://dx.doi.org/10.12775/ CJFA.2017.013.

Ciemleja, G., \& Lace, N. (2011). The model of sustainable performance of small and medium-sized enterprise. Engineering economics, 22(5), 501-509. http://dx.doi. org/10.5755/j01.ee.22.5.968.

European Commission (2007). Commission regulation (EC) No 1347/2007, Official Journal of the European Union, L 300/32.

Ernst \& Young (2009). IFRS 8 Operating Segments. Implementation Guidance, http:// www.ey.com/Publication/vwLUAssets/IFRS_8_Operating_segments_Implementation_guidance/\$FILE/IFRS_8_Operating_Segments_IG.pdf (accessed: 28.06.2009).

Hart, S., \& Roslender, R. (2003). In Search of Strategic Management Accounting: Theoretical and Field Study Perspectives. Management Accounting Research, 14(3), 255-279. http://dx.doi.org/10.1016/S1044-5005(03)00048-9.

Hofbauer, G. (2017). Technische Beschaffung - Der Beschaffungsprozess, Schriftenreihe Strategisches Beschaffungsmanagement, Band 2. Berlin: Seiten.

IFRS 8 (2017). International Financial Reporting Standard 8 - Operating Segments: 29th March, 2017, http://www.iasplus.com/en/news/2017/03/ifrs-8-improvements (accessed: 29.03.2017).

Khocha, N. (2017). The organization of management accounting at small enterprises in Ukraine. Baltic Journal of Economic Studies, 3(4), 271-279.

Mitev, B. (2016). Essential Characteristics of Strategic Alliances. Izvestia, Journal of the Union of Scientists - Varna, Economic Sciences Series, 1, 109-115.

Papazov, E. (2012). Strategic management. Ruse: Avangard print. (in Bulgarian)

Papazov, E., \& Mihaylova, L. (2011). Product Diversification in SMEs as Anti-Crisis Response. Izvestiya - Journal of Varna Economic University, 2, 122-127. (in Bulgarian)

Papazov, E., \& Mihaylova, L. (2015). Approaches to strategy-driven sectoral competition analysis of business organizations. In Perspectives of Business and Entrepreneurship Development. Proceedings of Selected Papers. Brno: Brno University of Technology.

Pepur, M., Mihanović, Z., \& Pepur, S. (2013). Analysis of the effect of perceived service quality to the relationship quality on the business-to-business market. Management: Journal of Contemporary Management Issues, 18(2), 97-109.

Ruland, R. (1984). Duty, obligation and responsibility in accounting policy making. Journal of Accounting and Public Policy, 14(3), 223-237. http://dx.doi.org/10.1016/02784254(84)90018-8.

Šimberová, I. (2008). Marketing approach to stakeholder management. In A. Pabedinskaitè (Ed.). 5th International Scientific Conference "Business and Management". Vilnius: Technika. 
Simeonov, O., \& Lambovska, M. (2012). A Suggestion about Potentialities for the SWOT Analysis' Development concerning Threats. Economics and Management, 2(1), 94$-103$.

Škoda, M., Lengyelfalusy, T., \& Gabrhelová, G. (2017). Creative accounting practices in Slovakia after passing financial crisis. Copernican Journal of Finance \& Accounting, 6(2), 71-86. http://dx.doi.org/10.12775/CJFA.2017.012.

Trifonova, S., \& Atanassov, A. (2016). Assessing the Impact of the Global Financial Crisis on Bulgaria's Economy from the Sector Perspective. International Journal of Emerging Research in Management \& Technology, 5(5), 5-19.

Yonkova, B. (2005). Sectoral information in the system of financial reporting and managerial accounting. Journal "Economic alternatives", 7(1), 94-110. 